\title{
PENGARUH PEMBERIAN PENDIDIKAN \\ KESEHATAN AUDIOVISUAL TENTANG REPRODUKSI REMAJA TERHADAP PENGETAHUAN PERILAKU SEKSUAL PRANIKAH
}

\author{
EFFECTS OF GIVING AUDIOVISUAL HEALTH \\ EDUCATION ABOUT ADOLESCENT REPRODUCTION \\ TO THE KNOWLEDGE OF PREMARITAL SEXUAL \\ BEHAVIOR
}

\author{
Gusti Ayu Indah Puspa Ranni ${ }^{1}$, Ns. R. Tri Rahyuning Lestari, S.Kep., M.Biomed ${ }^{2}$, Ns. \\ Niken Ayu Merna Eka Sari, S.Kep., M. Biomed ${ }^{3}$ \\ Jurusan Keperawatan Stikes Wira Medika Bali
}

\begin{abstract}
ABSTRAK
Remaja merupakan individu yang menunjukkan tanda-tanda seksual sekunder sampai mencapai kematangan seksual. Kematangan organ seksual dan perubahan hormonal menyebabkan munculnya dorongan seksual pada remaja dalam perilaku seksual. Penelitian ini bertujuan untuk mengetahui pengaruh pemberian pendidikan kesehatan terhadap tingkat pengetahuan seksual parnikah. Jenis penelitian yang digunakan adalah eksperimental dengan rancangan quasi experiment dengan metode pendekatan nonequivalent control grup design. Pendekatan non- equivalent control grup design. Jumlah sampel dalam penelitian ini sebanyak 94 responden dengan teknik stratified random sampling. Hasil penelitian menunjukkan pada kelompok perlakuan sebanyak 47 (100\%) dalam kategori baik sedangkan pada kelompok kontrol sebanyak 2 (4.0\%) dalam kategori kurang, 32 (68.0\%) dalam kategori cukup dan 13 ( 28.0\% ) dalam kategori baik. Berdasarkan uji statistik Wilcoxon Signed Rank Test diketahui $\mathrm{p}=0,000$ sehingga $\mathrm{p}<\alpha$ nikai $\alpha=0,05$, maka $\mathrm{H} 0$ ditolak berarti ada pengaruh pemberian pendidikan kesehatan. Remaja diharapkan dapat meningkatkan pengetahuan dan pemahaman tentang pendidikan kesehatan, sehingga dapat melakukan pencegahan perilaku seksual pranikah.
\end{abstract}

Kata Kunci: Pendidikan Kesehatan Audiovisual, Remaja, Pengetahuan Perilaku Seksual

\section{ABSTRACT}

Adolescents are individuals who show the secondary sexual signs until they reach sexual maturity. Maturity of sexual organs and hormonal changes cause the emergence of sexual urges in adolescents in sexual behavior. This study aims to determine the effect of providing health education to the level of knowledge on premarital sexual behavior. This type of research is an experimental quasi-experimental design with a non-equivalent control group design approach. Non-equivalent control group design approach. The number of samples in this study were 94 respondents with stratified random sampling technique. The results showed that 47 (100\%) in the treatment group were in the good 
Bali Medika Jurnal.

Vol 7 No 1, 2020: 46-60

ISSN : 2615-7047

DOI: https://doi.org/10.36376/bmj.v7i1

category while in the control group were $2(4.0 \%)$ in the poor category, $32(68.0 \%)$ in the adequate category and $13(28.0 \%)$ in the good category. Based on the Wilcoxon Signed Rank Test statistical test it is known that $p=0,000$ so that $p<\alpha$ nikai $\alpha=0.05$, then HO is rejected, meaning there is an influence of health education. Adolescents are expected to increase their knowledge and understanding of health education, so that they can prevent premarital sexual behavior.

Keywords: Audiovisual Health Education, Teenagers, Knowledge of Sexual Behavior

\author{
Alamat Korespondensi $\quad$ : Jl. Tirtanadi No.19, Sanur Kauh, Kec. Denpasar Sel, Bali 80228 \\ Email : :ndahpusparanni@gmail.com
}

\title{
PENDAHULUAN
}

Kesehatan reproduksi merupakan keadaan sehat secara fisik, mental dan sosial secara utuh, tidak semata - mata bebas dari penyakit atau kecacatan yang berkaitan dengan sistem, fungsi dan proses reproduksi (Kemenkes RI, 2014). Pendidikan kesehatan reproduksi remaja merupakan pendidikan kesehatan yang dilakukan dengan menyebarkan pesan, menanamkan keyakinan sehingga remaja tidak saja sadar, tahu dan mengerti tetapi juga mau dan dapat melakukan anjuran yang berhubungan dengan kesehatan reproduksi (Katharina \& Yuliana, 2017). Keberhasilan dalam pemberian pendidikan kesehatan pada remaja tergantung kepada komponen pembelajaran.

Audio visual merupakan salah satu media yang menyajikan informasi atau pesan melalui dengar dan lihat (Purwono et al., 2014). Perkembangan zaman saat ini yang begitu pesat, membuat dunia teknologi menjadi tambah modern. Karena itulah muncul berbagai media pembelajaran yang dapat mendukung suatu proses belajar mengajar. Salah satu media yang mengalami perkembangan adalah media audio visual (Febliza \& Afdal, 2015).

WHO (2016) menyebutkan bahwa sekitar 12 juta remaja perempuan yang berumur 15-19 tahun di negara berkembang, mengalami kehamilan setiap tahun dan hampir setengah kehamilan tersebut (49\%) merupakan kehamilan yang tidak diinginkan. Hasil Survey Kesehatan Reproduksi Remaja Indonesia (SKRRI) (2019) terdapat beberapa alasan remaja melakukan seks pranikah yaitu terjadi begitu saja, rasa penasaran, dipaksa pacar/pasangan, ingin menikah dan adanya pengaruh teman. Menurut KISARA PKBI Bali hasil pencatatan pada tahun 2016 menunjukkan sebanyak 880 remaja atau $73,33 \%$ telah menjalin hubungan asmara (pacaran), sebanyak 57 pasangan atau $6,48 \%$ pasangan tersebut sudsh aktif melakukan hubungan seksual. Rata-rata mereka mengaku hubungan intim itu dilakukan antara usia 11-15 tahun. Menurut data kajian di SMK Negeri 3 Denpasar sebanyak 2 siswa mengalami kehamilan yang tidak diinginkan.

Pendidikan kesehatan reproduksi remaja merupakan pendidikan kesehatan yang dilakukan dengan menyebarkan pesan, menanamkan keyakinan sehingga remaja tidak saja sadar, tahu dan mengerti tetapi juga mau dan dapat melakukan anjuran yang berhubungan dengan kesehatan reproduksi (Katharina \& Yuliana, 2017). Adapun faktor-faktor yang mempengaruhi remaja melakukan 
hubungan seksual pranikah menurut Aryani (2010) yaitu adanya dorongan biologis, pemberian fasilitas (termasuk uang) pada remaja secara berlebihan, pergeseran nilai-nilai moral dan etika di masyarakat, serta kemiskinan mendorong terbukanya kesempatan bagi remaja khususnya wanita untuk melakukan hubungan seks pranikah.

Media audiovisual merupakan salah satu media yang menyajikan informasi atau pesan secara audiovisual (Dermawan, 2009). Audiovisual memberikan kontribusi yang sangat besar dalam perubahan perilaku masyarakat, terutama dalam aspek informasi dan persuasi. Media audiovisual memiliki dua elemen yang masing masing mempunyai kekuatan yang akan bersinergi menjadi kekuatan yang besar.

Berdasarkan pemaparan diatas Maka peneliti tertarik untuk mengambil judul "Pengaruh Pemberian Pendidikan Kesehatan Audiovisual Tentang Reproduksi Remaja Terhadap Pengetahuan Perilaku Seksual Pranikah Di SMK Negeri 3 Denpasar".

\section{METODE PENELITIAN}

Jenis penelitian yang digunakan dalam penelitian ini adalah penelitian eksperimental dengan rancangan quasi experiment dengan metode pendekatan non-equivalent control grup design. Teknik yang digunakan dalam pengambilan sempel penelitian ini adalah teknik probability sampling dengan metode stratified random sampling. Jumlah sampel pada penelitian ini sebanyak 94 responden pada tanggal 25 Novemberr 2019 yang dipilih sesuai kriteria penelitian. Instrumen pengumpulan data menggunakan kuesioner. Kuesioner yang digunakan dalam penelitian ini untuk mengukur pengetahuan perilaku seksual remaja dalam mengetahui serta memahami masalah seksual pranikah pada remaja dengan interpretasi yaitu, kurang, cukup dan baik. Uji koreasi dalam penelitian ini menggunakan uji statistik Wilcoxon Signed Rank Test dengan tingkat kesalahan $\alpha=0,05$.

\section{HASIL}

\section{HASIL DAN PEMBAHASAN}

Karakteristik responden dalam penelitian ini antara lain umur, jenis kelamin, Karakteristik yang telah diteliti kemudian didistribusikan ke dalam tabel sebagai berikut :

Tabel 1 Distribusi Karakteristik Responden

$\begin{array}{cccc}\begin{array}{c}\text { Keterangan Subyek } \\ \text { Penelitian }\end{array} & \frac{\text { Kelompok Perlakuan }}{\text { Frekuensi Usia }} & \\ & & & \\ & 16 & 14 & 29.8 \% \\ & 17 & 16 & 34.0 \% \\ 18 & 17 & 36.2 \%\end{array}$


Bali Medika Jurnal.

Vol 7 No 1, 2020: 46-60

ISSN : 2615-7047

DOI: https://doi.org/10.36376/bmj.v7i1

\begin{tabular}{lll}
\hline & Jenis Kelamin & Persentase (\%) \\
\hline Laki-laki & 12 & $25.5 \%$ \\
\hline Perempuan & 35 & $74.5 \%$ \\
\hline
\end{tabular}

\section{Kelompok Kontrol}

\begin{tabular}{lll} 
Keterangan & Frekuensi & Persentase (\%) \\
Subyek & & \\
Penelitian & & \\
\hline
\end{tabular}

\begin{tabular}{|c|c|c|}
\hline \multicolumn{3}{|c|}{ Usia } \\
\hline 16 & 14 & $29.8 \%$ \\
\hline 17 & 16 & $34.0 \%$ \\
\hline 18 & 17 & $36.2 \%$ \\
\hline \multicolumn{3}{|c|}{ Jenis Kelamin } \\
\hline Laki-laki & 16 & $34.0 \%$ \\
\hline Perempuan & 31 & 66.0 \\
\hline Jumlah & 94 & $100 \%$ \\
\hline Responden & & \\
\hline
\end{tabular}

Berdasarkan tabel 1 pada kelompok perlakuan dan kontrol sebagian besar berusia 18 tahun (36.2\%). Berdasarkan jenis kelamin pada kelompok perlakuan dari 47 siswa terdapat $35(74.5 \%)$ berjenis kelamin perempuan. pada kelompok kontrol dari 47 siswa terdapat $31(66.0 \%)$ berjenis kelamin perempuan.

Hasil pengamatan pengetahuan perilaku seksual menggunakan kuesioner dapat dilihat sebagai berikut :

Tabel 2 Distribusi frekuensi kelompok perlakuan pretest.

\begin{tabular}{llccc} 
& \multicolumn{4}{c}{ Kelompok Perlakuan Pretest } \\
\cline { 3 - 5 } & & Pengetahuan & Frekuensi & Persentase \\
\cline { 3 - 5 } No & Kurang & 1 & 2.0 \\
\hline 1 & Cukup & 46 & 98.0 \\
\hline 2 & Baik & 0 & 0 \\
\hline 3 & \multicolumn{5}{c}{ Total } & $\mathbf{4 7}$ \\
\hline \multicolumn{5}{c}{$\mathbf{1 0 0 \%}$}
\end{tabular}

Berdasarkan tabel 2.1 menunjukkan bahwa dari sampel siswa yang diteliti sebelum diberikan penerapan metode audiovisual di SMK Negeri 3 Denpasar, didapatkan lebih banyak siswa dengan pengetahuan cukup yaitu 46 siswa $(98,0 \%)$. 
Bali Medika Jurnal.

Vol 7 No 1, 2020: 46-60

ISSN : 2615-7047

DOI: https://doi.org/10.36376/bmj.v7i1

Tabel 3 Distribusi frekuensi kelompok perlakuan posttest

Kelompok perlakuan Posttest

\begin{tabular}{cccc} 
& \multicolumn{4}{c}{ Kelompok perlakuan Posttest } \\
\cline { 2 - 5 } No & Pengetahuan & Frekuensi & Persentase \\
\hline 1 & Kurang & 0 & 0.0 \\
\hline 2 & Cukup & 0 & 0.0 \\
\hline 3 & Baik & 47 & 100 \\
\hline \multicolumn{5}{c}{ Total } & $\mathbf{4 7}$ \\
\hline \multicolumn{5}{c}{$\mathbf{1 0 0 \%}$}
\end{tabular}

Berdasarkan tabel 3 menunjukkan setelah diberikan intervensi penerapan metode audiovisual tentang pendidikan kesehatan pada 47 sampel yang diteliti, didaptkan hasil siswa dengan nilai baik yaitu sebanyak 47 (100\%).

Tabel 4 Distribusi frekuensi kelompok kontrol prettest

Kelompok Kontrol Prettest

\begin{tabular}{|c|c|c|c|}
\hline No & Pengetahuan & Frekuensi & Persentase \\
\hline 1 & Kurang & 24 & 51.0 \\
\hline 2 & Cukup & 23 & 49.0 \\
\hline 3 & Baik & 0 & 0.0 \\
\hline
\end{tabular}

Total

47

$100 \%$

Berdasarkan tabel 4 menunjukkan bahwa dari sampel siswa yang diteliti sebelum diberikan penerapan metode ceramah di SMK Negeri 3 Denpasar, didapatkan hasil siswa dengan pengetahuan perilaku seksual pranikah kurang sebanyak 24(51,0\%), cukup $23(49 \%)$.

Tabel 5 Distribusi frekuensi kelompok kontrol posttest

Kelompok Kontrol Posttest

\begin{tabular}{|c|c|c|c|}
\hline No & Pengetahuan & Frekuensi & Persentase \\
\hline 1 & Kurang & 2 & 4.0 \\
\hline 2 & Cukup & 32 & 68.0 \\
\hline 3 & Baik & 13 & 28.0 \\
\hline & Total & 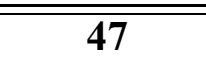 & 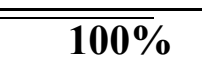 \\
\hline
\end{tabular}


Berdasarkan tabel 5 menunjukkan setelah diberikan intervensi penerapan metode ceramah tentang pendidikan kesehatan pada 47 sampel yang diteliti, didapatkan hasil siswa dengan nilai kurang $2(4,00 \%)$, cukup $32(68,0 \%)$, baik $13(28,0 \%)$.

Hasil analisis bivariat pengetahuan perilaku seksual dapat dilihat sebagai berikut :

Tabel 6. Hasil Analisis Data

\begin{tabular}{ccc} 
Analisis & P value & $R$ \\
\hline $\begin{array}{c}\text { Wilcox } \\
\text { on Signed } \\
\text { Rank Test }\end{array}$ & 0,00 & -6.788
\end{tabular}

Dalam penelitian ini pengaruh pemberian pendidikan kesehatan audiovisual tentang reproduksi remaja terhadap pengetahuan perilaku seksual pranikah, dapat dilakukan dengan uji statistik Wilcoxon Sign Rank Test yang menunjukkan hasil uji statistic sebesar pvalue 0,000 pada tingkat kemaksaan $\alpha=$ 0,05 dengan $\mathrm{H} 1$ diterima $\mathrm{H} 0$ ditolak, jadi dapat disimpulkan bahwa ada pengaruh pemberian pendidikan kesehatan audiovisual tentang reproduksi remaja terhadap pengetahuan perilaku seksual pranikah di SMK Negeri 3 Denpasar.

\section{PEMBAHASAN}

Pengetahuan perilaku seksual pranikah di SMK Negeri 3 Denpasar sebelum diberikan pendidikan kesehatan dengan metode audiovisual

Berdasarkan hasil penelitian pengetahuan perilaku seksual pranikah sebelum diberikan pendidikan kesehatan dengan metode audiovisual didapatkan hasil bahwa dari 47 siswa terdapat 46 siswa $(98,0 \%)$ dengan kategori cukup.

Penelitian ini sejalan dengan penelitian yang dilakukan oleh Mihora (2018) yang berjudul Pengaruh Penyuluhan Kesehatan Reproduksi terhadap Pengetahuan dan Sikap Seks Pranikah Pada Siswa Kelas X diperoleh data bahwa nilai pengetahuan perilaku seksual pranikah dari 40 siswa sebanyak 1 siswa $(2,5 \%)$ dalam kategori kurang, 23 siswa (57\%) dalam kategori cukup, 16 siswa (40\%) dalam kategori baik. Hasil penelitian ini juga sejalan dengan Widiyanto \& Sari (2013) yang berjudul Pengaruh Pemberian Pendidikan Kesehatan Reproduksi Remaja Terhadap Pengetahuan Tentang Perilaku Seksual dari 35 siswa sebanyak 22 siswa (63\%) dalam kategori kurang, 13 siswa (37\%) dalam kategori cukup. Hasil penelitian ini juga sejalan dengan Handayani \& Putri (2017) yang berjudul Pengaruh Pendidikan Kesehatan Dengan media Video Terhadap Tingkat Pengetahuan Tentang Pencegahan HIV/AIDS Di Sma Negeri 1 Parigi Kabupaten Pangandaran diperoleh data sebanyak 76 sampel 1 siswa $(1,3 \%)$ dalam kategori baik, 50 siswa $(65,8 \%)$ dalam kategori cukup. Hal ini disebabkan karena belum 
diberikannya pendidikan pengetahuan sehingga hasil yang didapatkan tidak maksimal.

Hasil pengetahuan perilaku seksual pranikah remaja sebelum diberikan penerapan metode audiovisual adalah pada kategori cukup, menurut Benita et al. (2012) ada beberapa faktor yang mempengaruhi pengetahuan diantaranya adalah lingkungan sosial akan mendukung tingginya pengetahuan seseorang, pun budaya sangat berpengaruh terhadap tingkat pengetahuan seseorang, karena informasi yang baru akan disaring kira-kira sesuai tidak dengan budaya yang ada dan agama yang dianut, Hal ini didukung oleh penelitian Putriani (2010) bahwa orangtua sangat berpengaruh dalam pemahaman mengenai pengetahuan kesehatan reproduksi karena anak - anak cenderung mengontrol perilaku kesehatan reproduksi sesuai dengan pemahaman yang diberikan orangtua nya. Hal ini mencerminkan kurangnya pemahaman remaja tentang keterampilan hidup sehat, risiko hubungan seksual dan kemampuan untuk menolak hubungan yang tidak mereka inginkan (Kementerian Kesehatan RI, 2015).

Menurut peneliti, kategori cukup yang didapatkan oleh responden disebabkan karena kurangnya siswa dalam mencari informasi tentang pendidikan reproduksi terkait dengan perilaku seksual pranikah, minimnya pelajaran yang diberikan disekolah mengenai pendidikan kesehatan, kurangnya informasi dari orang tua kepada anak-anaknya, serta kurangnya lingkungan siswa yang ingin mengetahui penting serta bahaya dari perilaku seksual pranikah. Pada hasil penelitian ini, kategori kurang merupakan salah satu kegagalan dan berdampak negative bagi siswa, maka dari itu pentingnya pembelajaran tentang kesehatan reproduksi mengenai perilaku seksual pranikah diadakan di sekolah dan di terapkan juga dirumah kepada orang tua siswa.

\section{Pengetahuan perilaku seksual pranikah di SMK Negeri 3 Denpasar setelah diberikan pendidikan kesehatan dengan metode audiovisual}

Berdasarkan penelitian ini setelah diberikan pendidikan kesehatan engan metode audiovisual didapatkan pada 47 siswa (100\%) dikategorikan baik.

Penelitian ini sejalan dengan penelitian Mihora (2018) yang berjudul Pengaruh Penyuluhan Kesehatan Reproduksi terhadap Pengetahuan dan Sikap Seks Pranikah Pada Siswa Kelas X diperoleh data bahwa nilai pengetahuan perilaku seksual pranikah. Hasil penelitian ini didapatkan setelah menggunakan metode audiovisual dan dilakukan posttest didapatkan hasil 40 siswa (100\%) berpengetahuan baik. Hasil penelitian ini juga sejalan dengan Widiyanto \& Sari (2013) yang berjudul Pengaruh Pemberian Pendidikan Kesehatan Reproduksi Remaja Terhadap Pengetahuan Tentang Perilaku Seksual dari 35 siswa sebanyak 33 siswa $(94,0 \%)$ dengan kategori baik. Hasil Penelitian ini sejalan dengan Handayani \& Putri (2017) yang berjudul Pengaruh Pendidikan Kesehatan Dengan media Video Terhadap Tingkat Pengetahuan Tentang Pencegahan HIV/AIDS di SMA Negeri 1 Parigi Kabupaten Pangandaran diperoleh data sebanyak 76 sampel 48 siswa dengan kategori baik (63,2\%), dan kategori cukup 26 siswa $(34,2 \%)$. Hal ini dikarenakan kelompok perlakuan diberikan penyuluhan menggunakan alat bantu media penyuluhan audiovisual sehingga lebih menarik, sehingga hasil yang didapatkan dengan kategori baik.

Hasil pengetahuan perilaku seksual pranikah remaja sesudah diberikan penerapan metode audiovisual terdapat pada kategori baik ,Hal ini sesuai dengan 
pendapat Notoatmodjo (2013) yang menyatakan bahwa pengetahuan merupakan hasil tahu dan ini terjadi setelah orang melakukan pengindraan terhadap suatu objek tertentu. Penginderaan ini terjadi melalui panca indera manusia yaitu penglihatan, pendengaran, penciuman, rasa dan raba. Sebagian besar pengetahuan manusia diperoleh melalui mata dan telinga. Roger dalam Notoatmodjo (2013) mengatakan bahwa sebelum seseorang mengadopsi perilaku baru dalam diri seseorang terjadi proses sebagai berikut : a) awareness ; subyek menyadari atau mengetahui stimulus terlebih dahulu, b) interest ; subyek mulai tertarik pada stimilus, c) evaluation ; subyek menumbang baik \& tidaknya stimulus tersebut bagi dirinya, d) trial ; subyek telah menimbang perilaku yang baru, e) adaption ; subyek telah berperilaku baru sesuai dengan pengetahuan, kesadaran dan sikapnya terhadap stimulus. Menurut Notoatmodjo (2012) penggunaan audio visual saat pemberian pendidikan kesehatan dapat menarik minat responden untuk membaca dan mempermudah dalam memahami materi kesehatan yang disampaikan. Sehingga dapat membantu meningkatkan pengetahuan responden tentang pendidikan seks khususnya kesehatan reproduksi. Berdasarkan karakteristik responden didapatkan bahwa responden terbanyak berjenis kelamin perempuan dan berumur 16,17,18 tahun yang termasuk dalam kategori remaja akhir. Menurut Prawirohardjo (2013) mengatakan perempuan dengan rentan 12-20 tahun sangat rentan mengalami kejadian kehamilan diluar nikah, hal ini menunjukkan karakteristik perempuan lebih besar. Pada remaja akhir mempunyai ciri-ciri yaitu remaja menampakkan pengungkapan kebebasan diri, dalam mencari teman sebaya sudah mulai selektif, memiliki citra (gambaran, keadaan, perasaan) terhadap dirinya, dapat mewujudkan perasaan cinta, memiliki kemampuan berfikir khayal atau abstrak (Widyastuti, 2009). Dengan adanya ciri-ciri tersebut maka remaja harus mulai dibekali dengan pengetahuan yang memadai sehingga akan menjadi dasar pengembangan daya nalar dan jalan untuk memudahkan menerima informasi dan selanjutnya memberikan aplikasi terhadap sikap remaja dalam mencegah perilaku seksual pranikah (Notoatmodjo, 2012).

Menurut pendapat peneliti pemberian pendidikan kesehatan tentang pengetahuan perilaku seksual pranikah menggunakan metode audiovisual sangatlah efektif, dapat dibuktikan karena menggunakan metode audiovisual akan membangkitkan rasa keingintahuan siswa karena menggunakan gambar dan juga suara sehingga lebih memudahkan siswa untuk mengerti dan menyimak dengan baik apa yang diberikan.

\section{Pengetahuan perilaku seksual pranikah di SMK Negeri 3 Denpasar sebelum diberikan pendidikan kesehatan dengan metode ceramah}

Berdasarkan hasil penelitian pengetahuan perilau seksual pranikah sebelum diberikan pendidikan kesehatan dengan metode ceramah didapatkan hasil bahwa dari 47 siswa terdapat 24 siswa $(51,0 \%)$ dalam kategori kurang.

Penelitian ini sejalan dengan Astuti \& Purwati (2015) yang melakukan penelitian tentang Pengaruh Penyuluhan Kesehatan Reproduksi Melalui Media Audio Visual Terhadap Tingkat Pengetahuan Dan Sikap Tentang Kehamilan Remaja Di Luar Nikah Di Smk 17 Bantul Yogyakarta. Hasil penelitian didapatkan sebelum diberikan pengetahuan dengan metode ceramah 13 siswa $(48,1 \%)$ dengan kategori cukup, 14 siswa $(51,9)$ dengan kategori baik. dan dilakukan 
posttest didapatkan hasil 40 siswa (100\%) berpengetahuan baik. Hasil penelitian ini juga

sejalan dengan Widiyanto \& Sari (2013) yang berjudul Pengaruh Pemberian Pendidikan Kesehatan Reproduksi Remaja Terhadap Pengetahuan Tentang Perilaku Seksual dari 35 siswa sebanyak 25 siswa (71,0\%) dengan kategori cukup. Hasil Penelitian ini sejalan dengan Ana (2019) yang berjudul Pengaruh Pemberian Pendidikan Seks Terhadap Pengetahuan Dan Sikap Remaja Dalam Mencegah Perilaku Seks Di Luar Nikah Di Smk Negeri 1 Sewon dari 105 siswa didapatkan 86 siswa $(81,9 \%)$ dalam kategori baik, 19 siswa $(18,1 \%)$ dalam kategori cukup. Hal ini dikarenakan belum adanya pemberian pendidikan kesehatan.

Berdasarkan teori hasil pengetahuan perilaku seksual pranikah remaja sebelum diberikan penerapan metode ceramah dengan pendidikan kesehatan yaitu terbanyak adalah pada kategori kurang hal ini disebabkan karena hal ini sesuai dengan penelitian yang telah dilakukan oleh Udu \& Wiradirani (2015) tentang pengaruh intervensi penyuluhan terhadap pengetahuan kesehatan reproduksi. Hasil penelitian menunjukkan bahwa akan terjadi perbedaan hasil jika siswa tidak diberikan penjelasan terlebih dahulu. Sejalan dengan teori Notoatmodjo (2012), yang menyatakan bahwa informasi yang diperoleh dari pendidikan formal maupun non formal dapat memberikan pengaruh jangka pendek, sehingga menghasilkan perubahan atau peningkatan pengetahuan. Begitupun dengan pendapat Wawan \& Dewi (2012) yang menyatakan bahwa pengetahuan itu sendiri dipengaruhi oleh faktor pendidikan formal. Pengetahuan sangat erat hubungannya dengan pendidikan, dimana diharapkan bahwa dengan pendidikan yang tinggi maka orang tersebut akan semakin luas pula pengetahuannya. Akan tetapi perlu ditekankan, bukan berarti seseorang yang berpendidikan rendah mutlak berpengetahuan rendah pula. Hal ini mengingat bahwa peningkatan pengetahuan tidak mutlak diperoleh dari pendidikan formal saja, akan tetapi dapat diperoleh melalui pendidikan non formal.

Menurut pendapat peneliti dari hasil penelitian dengan kategori kurang dikarenakan belum adanya pemberian informasi kepada siswa sehingga menyebabkan hasil dalam kategori kurang, pentingnnya pendidikan kesehatan di luar sekolah pun bisa dilakukan sehingga meningkatkan pengetahuan siswa dalam pendidikan kesehatan, pengetahuan yang memadai sehingga akan menjadi dasar pengembangan daya nalar dan jalan untuk memudahkan menerima informasi.

\section{Pengetahuan perilaku seksual pranikah di SMK Negeri 3 Denpasar setelah diberikan pendidikan kesehatan dengan metode ceramah}

Pada penelitian ini setelah diberikan pendidikan kesehatan dengan metode ceramah ditemukan jumlah 32 siswa $(68,0 \%)$ dalam kategori cukup.

Penelitian ini sejalan dengan Astuti \& Purwati (2015) yang melakukan penelitian tentang Pengaruh Penyuluhan Kesehatan Reproduksi Melalui Media Audio Visual Terhadap Tingkat Pengetahuan Dan Sikap Tentang Kehamilan Remaja Di Luar Nikah Di Smk 17 Bantul Yogyakarta. Hasil penelitian didapatkan sesudah diberikan pengetahuan dengan metode ceramah 4 siswa $(14,8)$ dengan kategori cukup dan 23 siswa $(85,2 \%)$ dengan kategori baik. dan dilakukan posttest didapatkan hasil 40 siswa (100\%) berpengetahuan baik. Hasil penelitian ini juga sejalan dengan Widiyanto \& Sari (2013) yang berjudul Pengaruh 
Pemberian Pendidikan Kesehatan Reproduksi Remaja Terhadap Pengetahuan Tentang Perilaku Seksual dari 35 siswa sebanyak 18 (51,0\%) dalam kategori kurang dan 17 ( 49\%) siswa dengan kategori cukup. Hasil penelitian sejalan dengan Ana (2019) yang berjudul Pengaruh Pemberian Pendidikan Seks Terhadap Pengetahuan Dan Sikap Remaja Dalam Mencegah Perilaku Seks Di Luar Nikah Di Smk Negeri 1 Sewon dari 105 siswa diperoleh hasil 102 siswa (97,1\%) dengan kategori baik, 3 siswa (2,9\%) dalam kategori cukup.

Hal ini sesuai dengan teori Yuniarti (2007) yang menyatakan bahwa pendidikan kesehatan reproduksi adalah proses dimana fasilitator dengan sengaja dan penuh tanggung jawab memberikan pengaruh yang positif kepada peserta pendidikan kesehatan reproduksi, dengan tujuan agar peserta pendidikan kesehatan reproduksi dapat mengerti dan memahami materi-materi yang diberikan. Dengan adanya pendidikan kesehatan reproduksi dapat menurunkan kecenderungan perilaku seksual pada remaja. Penyampaian pendidikan kesehahatan dengan metode ceramah merupakan cara penyampaian pesan paling umum untuk berbagi pengetahuan dan fakta kesehatan. Namun metode ini mempunyai kelemahan, karena sering dilakukan secara sepihak tanpa memberikan kesempatan kepada peserta untuk aktif berperan serta. Oleh karena itu, metode ini akan menjadi efektif bila dilengkapi dengan tanya jawab dengan peserta, sehingga terjadi komunikasi dua arah (Notoatmodjo, 2012). Menurut Prawirohardjo (2013) tujuan dari pendidikan kesehatan reproduksi adalah bukan untuk menimbulkan rasa ingin tahu dan ingin mencoba hubungan seksual antar remaja, tetapi ingin menyiapkan agar remaja tahu tentang seksualitas dan akibat-akibat melakukan hubungan seksual tanpa mematuhi aturan hukum, agama, adat istiadat serta kesiapan mental dan material seseorang. Selain itu pendidikan kesehatan reproduksi juga bertujuan untuk memberikan pengetahuan dan mendidik anak agar berperilaku baik dalam hal seksual, sesuai dengan norma agama, sosial dan kesusilaan sehingga mampu menghargai kemampuan seksualnya dan hanya menyalurkan dorongan tersebut untuk tujuan tertentu (yang baik) dan pada waktu tertentu. Hasil penelitian ini sesuai dengan teori yang dikemukakan Depkes (2004) bahwa penyuluhan merupakan suatu proses penambahan pengetahuan dan kemampuan seseorang melalui teknik praktik belajar atau instruksi dengan tujuan mengubah atau mempengaruhi perilaku manusia secara individu, kelompok maupun masyarakat untuk dapat lebih mandiri dalam mencapai tujuan hidup sehat.

Menurut pendapat peneliti dari hasil yang diperoleh pemberian pemberian pendidikan kesehatan tentang pengetahuan perilaku seksual pranikah setelah menggunakan metode ceramah sangatlah baik, dilihat dari hasil pengetahuan sebelum dan sesudah diberikan metode ceramah namun pada ceramah siswa hanya bisa membaca dan mendengarkan materi yang diberikan. Dari penelitian yang dilakukan lebih efektif menggunakan metode audiovisual selain mendengar dan melihat audiovisual mempunyai kelebihan yaitu meningkatkan daya tarik siswa, mempermudah dalam menyampaikan pesan-pesan kesehatan.

Analisis pengaruh pemberian pendidikan kesehatan audiovisual tentang reproduksi remaja terhadap pengetahuan perilaku seksual pranikah di SMK Negeri 3 Denpasar. 
Analisis pengaruh pemberian pendidikan kesehatan audiovisual tentang reproduksi remaja terhadap pengetahuan perilaku seksual pranikah yang dilakukan di SMK Negeri 3 Denpasar. Pada pebelitian ini dibagi penjadi 2 kelompok, yaitu kelompok perlakuan dan kelompok kontrol. Pada kelompok perlakuan dengan metode audiovisual dilakukan pretest dan posttest, pada kelompok perlakuan mengalami peningkatan sebelum diberikan dengan metode audiovisual dan sesudah diberikan metode audiovisual, begitu pun juga pada kelompok kontrol dengan metode ceramah, pada kelompok kontrol juga mengalami peningkatan sebelum dilakukan metode ceramah dan sesudah dilakukan metode ceramah, namun pada kelompok perlakuan dengan metode audiovisual mengalami peningkatan yang signifikan dibandingan dengan kelompok kontrol dengan metode ceramah. Pada kelompok perlakuan sebelum dilakukan metode video didapatkan hasil 98,0\% dalam kategori kurang dan setelah diberikan metode video didapatkan 100\% dalam kategori baik. Pada kelompok Perlakuan sebelum diberikan metode ceramah didapatkan hasil 51,0\% dalam kategori kurang dan setelah diberikan metode ceramah didapatkan hasil $68,0 \%$ dalam kategori cukup. Hasil analisa pengaruh pemberian pendidikan kesehatan audiovisual tentang reproduksi remaja terhadap pengetahuan perilaku seksual pranikah menggunakan uji statistik Wicolxon Signed Rank Test di dapatkan nilai $\mathrm{p}=0,000$ dengan demikian $\mathrm{H} 0$ ditolak, yang artinya ada pengaruh pemberian pendidikan kesehatan audiovisual tentang reproduksi remaja terhadap pengetahuan perilaku seksual pranikah yang dilakukan di SMK Negeri 3 Denpasar tahun

2019.

Hasil penelitian ini sejalan dengan penelitian Mihora (2018) yang berjudul Pengaruh Penyuluhan Kesehatan Reproduksi terhadap Pengetahuan dan Sikap Seks Pranikah Pada Siswa Kelas X. Dengan mengguanakan metode audiovisual akan meningkatkan minat dan daya tarik siswa pendidikan kesehatan, dapat memudahkan menyampaikan pesan-pesan kesehatan, Hasil uji statistik dengan menggunakan uji Wilcoxon Related Sample pada data pretest dan posttest pengetahuan kelompok eksperimen menunjukkan $\mathrm{Z}$ hitung $(-5,327)$, hasil signifikasi dengan $\mathrm{p}(0,000)<\alpha(0,05)$ sehingga dapat dibuktikan terdapat perbedaan bermakna antara kelompok pretest dan posttest setelah diberikan penyuluhan. Sedangkan hasil uji statistik dengan menggunakan uji-t pada data pretest dan posttest sikap kelompok eksperimen menunujukkan nilai -t hitung ($8,021)<-$ t tabel $(-1,684)$ dan $\mathrm{p}(0,000)<\alpha(0,05)$, artinya ada perbedaan nilai rata-rata preteset dan posttest setelah diberikan penyuluhan. Ada pengaruh penyuluhan kesehatan reproduksi terhadap pengetahuan dan sikap seks pranikah pada siswa kelas X SMAN 1 Wawotobi tahun 2018. Penelitian ini sejalan dengan Nurjanah (2013) dengan judul Pengaruh Pendidikan Kesehatan Reproduksi Remaja Terhadap kecendrungan Perilaku Seksual Remaja. Penelitian ini menggunakan analisis statistic, dengan menggunakan analisis non parametric dengan teknik wilcoxon match pairs test didapatkan hasil $\mathrm{Z}$ sebesar $-3,027, \mathrm{p}$ sebesar $0,001(p<0,05)$ dsn nilai rerata pada pre test $=100,22$ sedangkan nilai rerata pada post test $=95,66$, yang berarti bahwa ada perbedan kecendrungan perilaku seksual yang sifnifikan sebelum dan sesudah diberikan pendidikan kesehatan reproduksi. Penelitian ini sejalan dengan Ana (2019) dengan judul 
Pengaruh Pemberian Pendidikan Seks Terhadap Pengetahuan Dan Sikap Remaja Dalam Mencegah Perilaku Seks Di Luar Nikah Di Smk Negeri 1 Sewon. Penelitian ini menggunakan analisis statistic, dengan menggunakan analisis non parametric dengan teknik wolcoxon match pairs test didapatkan hasil $Z$ sebesar $-3,027$, $p$ sebesar $0,001(p<0,05)$ dsn nilai rerata pada pre test $=100,22$ sedangkan nilai rerata pada post test $=95,66$, yang berarti bahwa ada perbedan kecendrungan perilaku seksual yang sifnifikan sebelum dan sesudah diberikan pendidikan kesehatan reproduksi.

Hasil penelitian ini sesaui dengan teori Notoatmodjo (2012) penggunaan audiovisual saat pemberian pendidikan kesehatan dapat menarik minat responden untuk membaca dan mempermudah dalam memahami materi kesehatan yang disampaikan. Sehingga dapat membantu meningkatkan pengetahuan responden tentang pendidikan seks khususnya kesehatan reproduksi. Media audiovisual merupakan media yang memiliki unsur suara dan unsur gambar baik yang dapat bergerak maupun tidak sehingga pesan disampaikan melalui indra pendengaran dan indra penglihatan. Menurut Notoatmodjo (2012) penggunaan audio visual saat pemberian pendidikan kesehatan dapat menarik minat responden untuk membaca dan mempermudah dalam memahami materi kesehatan yang disampaikan Notoatmodjo (2013) yang menyatakan bahwa pengetahuan merupakan hasil tahu dan ini terjadi setelah orang melakukan pengindraan terhadap suatu objek tertentu. Penginderaan ini terjadi melalui panca indera manusia yaitu penglihatan, pendengaran, penciuman, rasa dan raba. Sebagian besar pengetahuan manusia diperoleh melalui mata dan telinga. Terkait dengan hasil penelitian tersebut terdapat beberapa faktor yang berpengaruh terhadap tingkat pengetahuan, khususnya tingkat pengetahuan kesehatan reproduksi pada remaja. Faktor-faktor tersebut antara lain: semakin bertambah usia seseorang, diasumsikan bertambah pula pengetahuannya seiring dengan bertambahnya pengalaman dan kematangan diri.

Sebuah penelitian di India menunjukkan bahwa terjadinya pernikahan dini di usia kurang dari 18 tahun berhubungan dengan kurangnya pengetahuan yang dibutuhkan tentang kesehatan reproduksi, pendidikan yang baik akan meningkatkan pengetahuan dan juga memudahkan seseorang untuk memperoleh pengetahuan yang lebih tinggi. Pendidikan dalam hal ini dapat diperoleh secara formal maupun non formal, kondisi sosial dan ekonomi seseorang mempunyai peran dalam meningkatkan kesempatannya untuk memperoleh pengetahuan, pengaruh kelompok sebaya pada remaja dapat tercermin dalam sikap, pembicaraan dan perilaku seseorang, Paparan informasi mempengaruhi tingkat pengetahuan remaja dalam berbagai hal, termasuk tentang kesehatan reproduksi. Informasi yang didapatkan remaja dapat diperoleh melalui bermacam-macam sumber, seperti media masa, konseling, penyuluhan dan internet. Menurut Notoatmodjo (2012) penggunaan audio visual saat pemberian pendidikan kesehatan dapat menarik minat responden untuk membaca dan mempermudah dalam memahami materi kesehatan yang disampaikan. Sehingga dapat membantu meningkatkan pengetahuan responden tentang pendidikan seks khususnya kesehatan reproduksi.

Menurut pendapat penelitian bahwa pengetahuan kesehatan remaja juga berpengaruh pada media yang diberikan saat memberikan informasi. Dilihat dari hasil penelitian bahwa menggunakan metode audiovisual lebih efektif 
dibandingkan dengan metode ceramah, hal ini karenakan dalam pemberian dengan metode video menimbulkan rasa ingin tahu yang besar karena dalam metode video melibatkan indra pendengaran dan penglihatan akan memberikan keuntungan karena siswa akan lebih banyak belajar daripada jika materi pelajaran disajikan stimulasi pandang saja, belajar dengan menggunakan indra ganda (audio dan visual) yaitu indra pendengaran dan penglihatan akan memberikan keuntungan karena siswa akan lebih banyak belajar dari pada jika materi pelajaran disajikan stimulasi pandang saja atau dengar saja. Kelebihan media audiovisual dalam proses pembelajaran yaitu menyampaikan pembelajaran menjadi lebih baku, pembelajaran menjadi lebih menarik, pembelajaran menjadi lebih interaktif dengan diterapkannya teori belajar dan prinsip-prinsip psikologis yang diterima dalam partisipasi siswa, umpan balik dan penguatan, lama waktu pembelajaran dapat disingkat, kualitas hasil belajar dapat ditingkatkan, pembelajaran dapat diberikan kapan dan dimana diinginkan, sikap positif siswa terhadap apa yang mereka pelajari dan terhadap proses pembelajaran dapat ditingkatkan. Dapat dibuktikan pada hasil posttest menggunakan metode audiovisual didapatkan $100 \%$ siswa dengan pengetahuan baik, namun adapun fakor-faktor yang berpengaruh diantaranya usia, tingkat pendidikan, sosial dan budaya, lingkungan pergaulan dan paparan informasi, sehingga siswa harus rajin mencari informasi sendiri mengenai pengetahuan kesehatan.

\section{SIMPULAN}

\section{SIMPULAN DAN SARAN}

1. Pengetahuan sebelum diberikan pendidikan kesehatan audiovisual di SMK Negeri 3 Denpasar pada 47 siswa didapatkan sebagian besar 46 siswa (98,0\%) dengan kategori cukup.

2. Pengetahuan setelah diberikan pendidikan kesehatan audiovisual di SMK Negeri 3 Denpasar didapatkan sebagian besar pada 47 siswa $(100 \%)$ dikategorikan baik.

3. Pengetahuan sebelum diberikan pendidikan kesehatan ceramah di SMK Negeri 3 Denpasar didapatkan sebagian besar 24 siswa $(51,0 \%)$ dengan kategori kurang.

4. Pengetahuan setelah diberikan pendidikan kesehatan ceramah di SMK Negeri 3 Denpasar didapatkan sebagian besar 32 siswa $(68,0 \%)$ dalam kategori cukup

5. Dari hasil uji statistik Wicolxon Signeg Rank Test di dapatkan nilai $\mathrm{p}=0,000$ dengan demikian $\mathrm{H} 0$ ditolak, yang artinya ada pengaruh pemberian pendidikan kesehatan audiovisual tentang reproduksi remaja terhadap pengetahuan perilaku seksual pranikah yang dilakukan di SMK Negeri 3 Denpasar tahun 2019.

\section{SARAN}

1. Kepada tenaga kesehatan

Hasil penelitian ini dapat menjadi sumber informasi yang baik mengenai pendidikan kesehatan terhadap pengetahuan perilaku seksual 
pranikah, diharapkan perawat maupun petugas kesehatan lainnya agar aktif memberikan penyuluhan pendidikan kesehatan kepada siswa.

2. Kepada Orang Tua

Bagi orang tua di harapkan selalu memberikan pendidikan kesehatan dirumah untuk meningkatkan pengetahuan kesehatan perilaku seksual pranikah bagi anak.

3. Kepada Siswa SMK Negeri 3 Denpasar

Melalui hasil penelitian ini diharapkan siswa lebih meningkatkan pemahaman tentang reproduksi remaja terhadap pengetahuan perilaku seksual pranikah.

4. Kepada institusi pendidikan

Hasil penelitian ini diharapkan akan menjadi sumber acuan sehingga disarankan agar SMK Negeri 3 Denpasar mengundang pelayanan kesehatan atau puskes dalam untuk melakukan penyuluhan mengenai pendidikan kesehatan tentang reproduksi.

5. Kepada peneliti selanjutnya

Hasil penelitian ini diharapkan dapat digunakan sebagai bahan pertimbangan untuk mengembangkan penelitian selanjutnya mengenai pendidikan kesehatan

\section{DAFTAR PUSTAKA}

Ana, F. (2019). Pemberian Pendidikan Seks Terhadap Pengetahuan Dan Sikap Remaja Dalam Mencegah Perilaku Seks Di Luar Nikah Di Smk Negeri 1 Sewon. Universitas' Aisyiyah Yogyakarta.

Aryani, R. (2010). Kesehatan Remaja : Problem dan Solusinya. Salemba Medika.

Astuti, T. F. A. W., \& Purwati, Y. (2015). Pengaruh Penyuluhan Kesehatan Reproduksi Melalui Media Audio Visual terhadap Tingkat Pengetahuan dan Sikap tentang Kehamilan Remaja di Luar Nikah di SMK. STIKES'Aisyiyah Yogyakarta.

Benita, N. R., Dewantiningrum, J., \& Maharani, N. (2012). Pengaruh penyuluhan terhadap tingkat pengetahuan kesehatan reproduksi pada remaja siswa SMP Kristen Gergaji. Fakultas Kedokteran.

Depkes. (2004). Kesehatan Reproduksi. Bina Kesehatan Masyarakat.

Dermawan, S. (2009). Proses Pembelajaran Dalam Pendidikan Keperawatan. Tim.

Febliza, \& Afdal. (2015). Statistika Dasar Penelitian Pendidikan. Adefa Grafika.

Handayani, L., \& Putri, H. A. (2017). Pengaruh Pendidikan Kesehatan dengan Media Video terhadap Tingkat Pengetahuan tentang Pencegahan HIV/AIDS di SMA Negeri 1 Parigi Kabupaten Pangandaran. Universitas' Aisyiyah Yogyakarta.

Katharina, T., \& Yuliana, Y. (2017). Pengaruh Penyuluhan Kesehatan Reproduksi melalui Audio Visual dengan Hasil Pengetahuan Setelah Penyuluhan pada Remaja SMA Negeri 2 Pontianak Tahun 2017. Jurnal Kebidanan, 8(1).

Kemenkes RI. (2014). Profil Kesehatan Indonesia. Kemenkes RI.

Kementerian Kesehatan RI. (2015). InfoDatin Pusat Data dan Informasi 
Bali Medika Jurnal.

Vol 7 No 1, 2020: 46-60

ISSN : 2615-7047

DOI: https://doi.org/10.36376/bmj.v7i1

Kementerian Kesehatan RI Situasi Kesehatan Reproduksi Remaja. Kementerian Kesehatan RI.

Mihora, D. P. E. (2018). Pengaruh Penyuluhan Kesehatan Reproduksi terhadap Pengetahuan dan Sikap Seks Pranikah Pada Siswa Kelas X SMAN 1 Wawatobi Tahun 2018. Politeknik Kesehatan Kendari.

Notoatmodjo. (2012). Promosi Kesehatan dan Perilaku Kesehatan. Rineka Cipta. Notoatmodjo. (2013). Pendidikan dan Perilaku Kesehatan. Rineka Cipta.

Nurjanah, Y. D. (2013). Pengaruh Pendidikan Kesehatan Reproduksi Terhadap Kecenderungan Perilaku Seksual Remaja. Universitas Muhammadiyah Surakarta.

Prawirohardjo, S. (2013). Hipertensi dalam kehamilan dalam: Ilmu Kebidanan (4th ed.). Bina Pustaka.

Purwono, J., Yutmini, S., \& Anitah, S. (2014). Penggunaan media audio-visual pada mata pelajaran ilmu pengetahuan alam di Sekolah Menengah Pertama Negeri 1 Pacitan. Jurnal Teknologi Pendidikan Dan Pembelajaran, 2(2), $127-144$.

Putriani, N. (2010). Faktor-faktor yang memepengaruhi pengetahuan remaja tentang kesehatan reproduksi di SMA Negeri 1 Mojogedang. Universitas Diponegoro.

Survey Kesehatan Reproduksi Remaja Indonesia (SKRRI). (n.d.). Kesehatan Remaja di Indonesia. 2012. Retrieved August 10, 2019, from http://www.idai.or.id

Udu, W. S. A., \& Wiradirani, P. Y. W. (2015). Pengaruh Intervensi Penyuluhan Terhadap Pengetahuan dan Sikap Remaja Tentang Kesehatan Reproduksi. Medula, 1(2).

Wawan, A., \& Dewi, M. (2012). Teori dan Pengukuran Pengetahuan, Sikap dan Perilaku Manusia. In Syafni. https://doi.org/doi: 10.1023/B:HYDR.0000008590.37567.fa

WHO. (2016). WHO Releases New Fact Sheets on Adolescent Contraceptive Use. Sexual and Reproductive Health. World Health Organization.

Widiyanto, B., \& Sari, A. M. (2013). Pengaruh Pemberian Pendidikan Kesehatan Reproduksi Remaja terhadap Pengetahuan tentang Perilaku Seksual. Jurnal Keperawatan Komunitas, 1(2).

Widyastuti, A. R. (2009). Peran Hukum dalam Memberikan Perlindungan terhadap Perempuan dari Tindak Kekerasan di Era Globalisasi. Mimbar HukumFakultas Hukum Universitas Gadjah Mada, 21(2), 395-408.

Yuniarti, D. (2007). Pengaruh Pendidikan Seks Terhadap Sikap Mengenai Seks Pranikah Pada Remaja. Universitas Gunadarma. 